Relations industrielles

Industrial Relations

\title{
What's Class Got To Do With It? American Society in the \\ Twenty-First Century edited by Michael ZWEIG, Ithaca and London: Cornell University Press, 2004, 240 pages, ISBN
} 0-8014-8899-0.

\section{David Camfield}

Volume 60, numéro 1, hiver 2005

URI : https://id.erudit.org/iderudit/011550ar

DOI : https://doi.org/10.7202/011550ar

Aller au sommaire du numéro

Éditeur(s)

Département des relations industrielles de l'Université Laval

ISSN

0034-379X (imprimé)

1703-8138 (numérique)

Découvrir la revue

Citer ce compte rendu

Camfield, D. (2005). Compte rendu de [What's Class Got To Do With It? American Society in the Twenty-First Century edited by Michael ZWEIG, Ithaca and London: Cornell University Press, 2004, 240 pages, ISBN 0-8014-8899-0.] Relations industrielles / Industrial Relations, 60(1), 198-199. https://doi.org/10.7202/011550ar d'utilisation que vous pouvez consulter en ligne. 
santé au travail. Le livre offre également une réflexion très originale ainsi qu'une profonde remise en question des postulats actuels en gestion des ressources humaines qui orientent la relation entre les personnes et le travail.

DENIS MORIN

Université du Québec à Montréal

\section{What's Class Got To Do With It? American Society in the Twenty-First Century}

edited by Michael Zweig, Ithaca and London: Cornell University Press, 2004, 240 pages, ISBN 0-8014-8899-0.

A new interdisciplinary field of teaching and research has begun to emerge in the US university system: working-class studies. It is distinguished from the established field of industrial relations and the smaller, but still more institutionally-secure field of labour studies, by its ambitious scope - "to understand how class works to shape our lives and the larger society" (16), in the words of economist Michael Zweig - and by its theoretical framework of class analysis. Teaching and research with this scope and conceptual approach have had an often-embattled presence in a range of disciplines in US and Canadian universities since the radicalization of the 1960s. However, the creation of working-class studies centres and programs at a handful of US post-secondary institutions, following the example of women's studies and other academic fields that have grown out of social movements, is a recent development. A Working-Class Studies Association was founded in 2003.

What's Class Got To Do With It? is intended as a contribution to workingclass studies. In it, Zweig, who has been active in establishing the new field and whose books include The Working Class Majority: America's Best Kept Secret (2000), presents eleven articles, mostly by academics in economics, labour studies and political science. The collection is organized into four thematic sections: "The Mosaic of Class, Race and Gender," "Class in a Global Economy," "Class and Working People," and "Class and Young Adults."
Zweig's introduction, "The Challenge of Working Class Studies," outlines a theoretical framework for understanding class primarily in terms of economic and political power, not income or lifestyle. He defines the working class as "made up of people who, when they go to work or when they act as citizens, have comparatively little power or authority" (4), and calculates this as $62 \%$ of the US labour force in 2002.

In Part I, Dorothy Sue Cobble's "When Feminism Had Class" introduces a number of women active in US labour between the Great Depression and the rise of Women's Liberation in the late 1960s. She believes they offer the contemporary women's and labour movements an understanding that gender, race and class inequalities and identities are inherently interconnected. Two chapters on race and class by Bill Fletcher $\mathrm{Jr}$ and R. Jeffrey Lustig argue that racial oppression has been and continues to be central to US capitalist society. They explain how this has had profound implications for the consciousness and action of US workers, and that the best response is anti-racist multiracial unionism and class politics.

Part II begins with William K. Tabb's overview of class in the global economy, which looks at the era of globalization as one of globalized capitalism, and critically examines the neoliberal economic orthodoxy of the Washington Consensus. Leo Panitch, the one Canadian contributor, provides what is perhaps the strongest chapter. 
His "political class analysis" situates 9/11 and its aftermath in the context of what he contends were the two key features of the late $20^{\text {th }}$ century: the rise of US power as the "first really global capitalist empire" and the "historic defeat of the Left" (80). Panitch incisively criticizes the AFL-CIO's opposition to China's admission to the WTO as well as the posturing of anti-labour Third World elites. Katie Quan's article follows with an analysis of the restructuring of the global garment industry. She argues that class analysis is vital in countering the competitive pressures that pit workers in different countries against each other.

The focus returns to the US in Part III. Here Frances Fox Piven analyses how "welfare reform" social policy increases the disciplining of workers by the labour market. This she usefully places within the broad contours of neoliberalism since the mid-1970s, with its efforts to weaken unions, intensify policing and incarceration and privatize pensions, noting that there is also a "wider cultural campaign to celebrate markets and reinforce labor [sic] market discipline" (120). Michael Yates's chapter discusses the US economy since the late 1990s and the situation of workers and unions in the post-9/11 period.

The subject of the final section of the book is class and youth. After Gregory DeFreitas and Niev Duffy's look at the trends in real wages and health insurance coverage and at attitudes to unions, the tone of the book changes. Some scholars in working-class studies focus on the experiences and identities of "blue-collar" working-class people rather than on political economy, class conflict and workers' organizations. This is evident in the two final chapters, Michelle M. Tokarczyk's on working-class students in post-secondary education and Barbara Jensen's on the cultural tensions experienced by people moving from the working class into the professional middle class.
Evaluations of What's Class Got To Do With It? will vary greatly, depending on one's theoretical perspective. For those who do not accept that class is a central social relation of domination in contemporary US society, this work will likely be of interest chiefly as an example of wrongheaded thinking. Those who, like this reviewer, share at least the basic theoretical orientation of the collection, will find it an accessible introduction to the many issues covered by the authors. In the Canadian context, What's Class Got To Do With It? is a valuable resource for those unfamiliar with US labour and society. A number of its chapters would also be useful readings in undergraduate courses whose focus is not the US.

In addition to the uneven quality and different understandings of important issues (e.g. "globalization" and international investment and trade agreements) that one expects to find in collections such as this one, there are a number of respects in which What's Class Got To Do With It? is less than satisfactory. Zweig's definition of class in terms of power is vulnerable to criticisms of class theory in a way that a theory of class as a social process and relationship in time rooted in surplus labour extraction is not. A number of authors conceptualize the working class in an overly narrow manner; this linked to the use of a concept of the professional middle class that is problematic in its effort to draw a class boundary on the basis of the workplace autonomy of salaried employees. Some chapters pay little or no attention to the mediation of class by race and gender. In general, gender does not receive enough attention in the collection, which contains no chapter on class and gender akin to the two chapters on race and class in the US. Nevertheless, What's Class Got To Do With It? is a solid introduction to a promising new field.

David Camfield University of Manitoba 